\title{
Effects of Mondia whitei extracts on the contractile responses of isolated rat vas deferens to potassium chloride and adrenaline
}

\author{
P. Watcho, ${ }^{1}$ D. Fotsing, ${ }^{1}$ F. Zelefack, ${ }^{2}$ T. B. Nguelefack, ${ }^{1}$ P. Kamtchouing, ${ }^{3}$ E. Tsamo, ${ }^{2}$ A. Kamanyi ${ }^{1}$
}

${ }^{1}$ Animal Physiology and Phytopharmacology Laboratory, Faculty of Science, University of Dschang, Box 67

Dschang, Cameroon.

${ }^{2}$ Department of Chemistry, Faculty of Science, University of Yaounde I, Box 812,

Yaounde, Cameroon.

${ }^{3}$ Animal Physiology Laboratory, Faculty of Science, University of Yaounde I, Box 812, Yaounde, Cameroon.

Received: 5.6 .2004

Revised: 13.9.2005

Accepted: 28.10.2005

Correspondence to:

Pierre Watcho

E-mail: pwatcho@yahoo.fr

\begin{abstract}
Objective: To investigate the effects of the methylene chloride:methanol $\left(\mathrm{CH}_{2} \mathrm{Cl}_{2}: \mathrm{MeOH}\right.$, 1:1) extract of the dried roots of Mondia whitei Linn and its hexane and methanol fractions on potassium chloride $(\mathrm{KCl})$ and adrenaline (Adr)-induced contractions of rat vas deferens.

Materials and Methods: Isolated strips of normal adult rat vas deferens were mounted in a Ugo Basile single-organ bath containing Krebs solution. Cumulative concentration-response curves of $\mathrm{KCl}\left(1-7 \times 10^{-2} \mathrm{M}\right)$ and adrenaline $\left(1.21-8.45 \times 10^{-7} \mathrm{M}\right)$ were established in the absence and presence of $M$. whitei $(50-400 \mu \mathrm{g} / \mathrm{ml})$. In separate experiments, after obtaining a stable plateau of contractions with $\mathrm{KCl}(60 \mathrm{mM}), M$. whitei samples $(50-400 \mu \mathrm{g} / \mathrm{ml})$ were added cumulatively to relax the preparation. In $\mathrm{KCl}(60 \mathrm{~m} M)$, containing depolarizing medium, cumulative concentration-contraction curve to $\mathrm{CaCl}_{2}\left(2-14 \times 10^{-2} \mathrm{M}\right)$ was elicited in the absence and presence of the hexane fraction of $\mathcal{M}$. whitei $(50-400 \mu \mathrm{g} / \mathrm{ml})$.

Results: All the $M$. whitei samples produced rightward shift of the concentration-response curves to $\mathrm{KCl}$ and Adr. At high concentration of the plant extracts $(400 \mu \mathrm{g} / \mathrm{ml})$, a decrease of the maximal response to the contractile agents was observed compared with that obtained with the control. All the three extracts produced concentration-dependent relaxation of the plateau of contraction induced by $\mathrm{KCl}$ and the hexane fraction appeared to be the more potent. In calcium-free physiological salt solution, the hexane fraction of $M$. whiteiproduced rightward shift to the concentration-response curve to $\mathrm{CaCl}_{2}$ and completely abolished the contractile effect of calcium at high concentration $(400 \mu \mathrm{g} / \mathrm{ml})$.

Conclusion: It is concluded that $M$. whitei extracts antagonized the contractile responses to $\mathrm{KCl}$ and $\mathrm{Adr}$ in isolated rat vas deferens, which could be due to the blockade of voltageoperated calcium channels.
\end{abstract}

Key Words: Epinephrine, in vitro preparation, $\mathrm{KCl}$.

\section{Introduction}

Mondia whitei is an aromatic plant of the Periplocaceae family. In Cameroon traditional medicine, it is referred to as Limte, Nkang Bongo, Yang, or La racine. The roots are used as spices or to treat urinary tract infection, jaundice, headache, diarrhea, ${ }^{[1]}$ and male sexual asthenia (impotence). ${ }^{[2]}$ We have observed a short-term androgenic ${ }^{[3]}$ (8 days of treatment) and a long-term reversible antispermatogenic and antifertility effects of the aqueous extract of $M$. whitei $(400 \mathrm{mg} / \mathrm{kg})$ in adult male rat. ${ }^{[4]}$ To the best of our knowledge, no work has been done with this plant on the physiology of the vas deferens, a structure of male reproductive system, which plays a principal role in male fertility through its contractile properties. ${ }^{[5]}$ The present work was carried out to investigate the in vitro effects of the $\mathrm{CH}_{2} \mathrm{Cl}_{2}: \mathrm{MeOH}$ extract of the dried roots of $M$. whitei and, its hexane and methanol fractions on $\mathrm{KCl}$ and adrenaline-induced contractions of the rat vas deferens, a study which could permit us to partially postulate the implication of the plant in the handling of some male reproductive disturbances such as infertility.

\section{Materials and Methods}

Animals

Healthy male albino rats (150-250 g, >90 days) of the Wistar strain were used in the present study. The animals were raised at room temperature with a natural light-dark cycle and maintained at standard rat diet and tap water given ad libitum.

Plant collection and extraction

Fresh roots of $M$. whitei were obtained from the local market and authenticated by Dr. Pinta Jonas of the Botany 
Department, Faculty of Science, University of Dschang, Cameroon. The roots were air-dried and ground using a mixer (Moulinex). The powdered roots $(700 \mathrm{~g})$ were soaked in 6 litres of $\mathrm{CH}_{2} \mathrm{Cl}_{2}: \mathrm{MeOH}$ (1:1) mixture at room temperature for $72 \mathrm{~h}$ and filtered. The solvent was removed by vacuum distillation and dried to obtain a black paste (76 g), referred to as the $\mathrm{CH}_{2} \mathrm{Cl}_{2}: \mathrm{MeOH}$ extract; $66 \mathrm{~g}$ of this mass were exhausted for $30 \mathrm{~min}$ in $2 \mathrm{l}$ of hexane and filtered. The solvent was removed as previously to obtain $10 \mathrm{~g}$ of hexane fraction. It was so proceeded to obtain the methanol $(10 \mathrm{~g})$ fraction of $M$. whitei. For each sample, the working solution (100 mg/ $\mathrm{ml}$ ) was prepared extemporarily by dissolving $1 \mathrm{~g}$ of paste in $2 \mathrm{ml}$ of $0.3 \%$ Tween 20 and $8 \mathrm{ml}$ of distilled water.

\section{Phytochemical tests}

The hexane and methanol fractions of $M$. whitei were treated with several reagents and spectroscopy and physical analysis (RMN, ${ }^{1} \mathrm{H}$ and ${ }^{13} \mathrm{C}$; mass spectrometry (SM) RMN, etc.) were performed. Positive results were obtained with the following constituents: steroids, triterpenes (mixture of amyrine $\alpha$ - and $\beta$-acetate, lupeol, $\beta$-sitosterol, and $\beta$ sitosterol glucoside) and aromatic (2-hydroxy-4methoxybenzaldehyde, 3-hydroxy-4-methoxy-benzaldehyde (vanillin), and 4-hydroxy-3-methoxy-benzaldehyde) compounds in the hexane fraction, sugar (glucose), and polyholosides $[\alpha$-D-glucopyranosyl (6-1)- $\beta$-D-glucopyranose and 1-methoxy- $\beta$-D-glucopyranosyl (6-1)-B-D-glucopyranose] in the methanol fraction.

\section{Contractions of the isolated vas deferens}

\section{Effects on agonist-induced contractile responses}

The rats were sacrificed by a blow on the head and bled to death by cutting the neck vessels. The vas deferens were promptly removed, cleansed of the connective tissue, and cut into two parts as to obtain a proximal portion nearer to the epididymis and a distal portion nearer to the sex accessory complex. The proximal part, which is more sensitive than the distal section, ${ }^{[6]}$ was used in the study and mounted in an organ bath of $20 \mathrm{ml}$ capacity containing fresh Krebs solution of the following composition $(\mathrm{mM} / \mathrm{l}): \mathrm{NaCl} 115, \mathrm{NaHCO}_{3} 25$, $\mathrm{CaCl}_{2}$ 2.5, KCl 4.7, $\mathrm{MgCl}_{2} 1.2, \mathrm{KH}_{2} \mathrm{PO}_{4} 1.2$, and D-glucose, 10 . The PSS was maintained at $37 \pm 0.5^{\circ} \mathrm{C}$ and continuously bubbled with air. The preparation was allowed to equilibrate for 45 min during which the bathing solution was changed every $15 \mathrm{~min}$. Cumulative concentration-response curves to agonists such as $\mathrm{KCl}\left(1.0-7.0 \times 10^{-2} \mathrm{M}\right)$ and adrenaline (1.21$\left.8.45 \times 10^{-7} \mathrm{M}\right)$ were recorded in the absence and presence of $M$. whitei samples (50-400 $\mu \mathrm{g} / \mathrm{ml})$. The contractile responses were expressed as a percentage of the maximal contractile response to $\mathrm{KCl}$ or Adr.

\section{Effects on KCl-induced maximal contraction}

In separate experiment, after having obtained a stable plateau of contractions [usually 15-20 min after challenging the preparation with supramaximal concentration of $\mathrm{KCl}(60$ $\mathrm{mM})], M$. whitei extract and its fractions (50-400 $\mu \mathrm{g} / \mathrm{ml}$ ) were used to relax the preparation in a cumulative manner. The relaxant effects were expressed as the percentage of inhibition of the plateau of contraction to $\mathrm{KCl}$.

Effects of the hexane fraction on calcium activity

In order to determine the effect of $M$. whitei extracts on calcium activity, the vas deferens was contracted with $\mathrm{KCl}$ and relaxed with PSS, and the bath solution replaced with a high $\mathrm{K}^{+}(70 \mathrm{mM}), \mathrm{Ca}^{2+}$-free Krebs solution containing EGTA (1 mM). Among the three $M$. whitei solutions, the hexane fraction showed maximum changes in the two previous experiments and was thus used in this investigation. Cumulative concentration-contraction curve was obtained by a stepwise increase in $\mathrm{CaCl}_{2}\left(2-14 \times 10^{-2} \mathrm{M}\right)$ in the absence and presence of the hexane fraction of $M$. whitei $(50-400 \mu \mathrm{g} /$ $\mathrm{ml})$. The contractile response was expressed as a percentage of the maximal contractile response to $\mathrm{CaCl}_{2}$.

In the above studies, contraction and inhibition (relaxation) of the vas deferens were recorded by means of an isometric transducer connected to a single-channel recorder (Ugo Basile, Italy), which was calibrated to record change in the tension generated on $\mathrm{g} V s$. $\mathrm{cm}$ displacement basis. The tension applied on the preparation was $0.8 \mathrm{~g}$.

One-way ANOVA with post hoc Dunnett's or NewmanKeuls multiple comparison test were performed. The value of $\mathrm{P}<0.05$ was considered to be statistically significant.

\section{Results}

Effects on agonist-induced contractile responses

In rat vas deferens, $\mathrm{KCl}\left(1-7 \times 10^{-2} \mathrm{M}\right)$ and adrenaline $(1.21-$ $\left.8.45 \mathrm{x} \quad 10^{-7} M\right)$ produced concentration-dependent contractions. In the presence of $M$. whitei $(50-400 \mu \mathrm{g} / \mathrm{ml})$, there were rightward shifts of the concentration-response curves to $\mathrm{KCl}$ and adrenaline with significant decrease in the maximal response. The hexane fraction of $M$. whitei produced comparatively more rightward shift and significant inhibition of the maximal response to $\mathrm{KCl}$ and Adr at highest concentration $(400 \mu \mathrm{g} / \mathrm{ml})$ as compared with the other fractions. [Figures 1 and 2, Table 1]

\section{Effects on the plateau of contraction induced by $\mathrm{KCl}$}

On the plateau of contraction induced by $\mathrm{KCl}(60 \mathrm{~m} M), M$. whitei extract and its fractions induced a concentrationdependent relaxant effects with the hexane fraction producing more relaxation with equivalent concentration (Table 2).

Effects of the hexane fraction on calcium activity

In calcium-free medium, the hexane fraction of $M$. whitei produced concentration-dependent rightward shift of the concentration-response curve of $\mathrm{CaCl}_{2}\left(2-14 \times 10^{-2} M\right)$ with significant decrease in the maximal response. [Figure 3 and Table 1]

\section{Discussion}

Smooth muscle contraction is dependent on the concentration of the cytosolic-free calcium, which activates the contractile elements. ${ }^{[7.81}$ In the present study, $\mathrm{KCl}$ and $\mathrm{Adr}$ induced contractions of isolated vas deferens of rat. The contractile effect of $\mathrm{KCl}$ is owing to a mechanism related to membrane depolarization and subsequent influx of external calcium through voltage-operated channels. ${ }^{[9]}$ Receptors for adrenaline are abundant in the proximal part of the vas deferens compared with the distal section. It contracts the vas deferens by interacting with either $\alpha_{1}$ or $\alpha_{2}$ receptors, whereas relaxation is generally associated with $B$-receptors. ${ }^{[10]}$ Stimulation of $\alpha_{1}$ receptors leads to the hydrolysis of phosphatidyl inositol into inositol triphosphate $\left(\mathrm{IP}_{3}\right)$ and 
Figure 1. Effects of various concentrations of the $\mathrm{CH}_{2} \mathrm{Cl}_{2}: \mathrm{MeOH}$ (1) extract of Mondia whitei (Mw) and its methanol (2) and hexane (3) fractions on cumulative concentration-response curves to $\mathrm{KCl}$. Each point represents mean of four experiments and the bars indicate SEM.

${ }^{a} \mathrm{P}<0.05$ and ${ }^{\mathrm{b}} \mathrm{P}<0.001$ significantly different from the corresponding control values.
Figure 2. Effects of various concentrations of the $\mathrm{CH}_{2} \mathrm{Cl}_{2}: \mathrm{MeOH}$ (1) extract of Mondia whitei (Mw) and its methanol (2) and hexane (3) fractions on cumulative concentration-response curves to Adrenaline. Each point represents mean of four experiments and the bars indicate SEM.

${ }^{a} \mathrm{P}<0.05$ and ${ }^{b} \mathrm{P}<0.001$ significantly different from the corresponding control values.
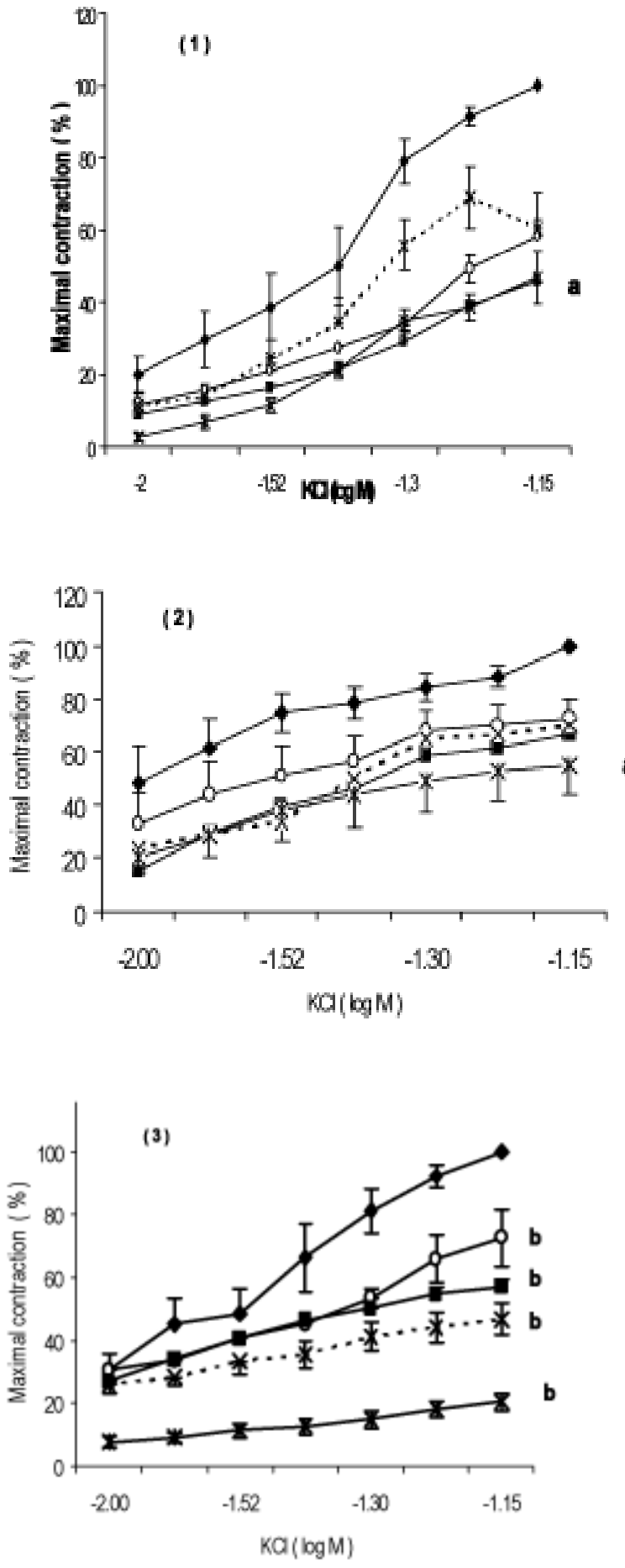

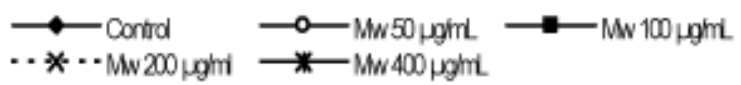
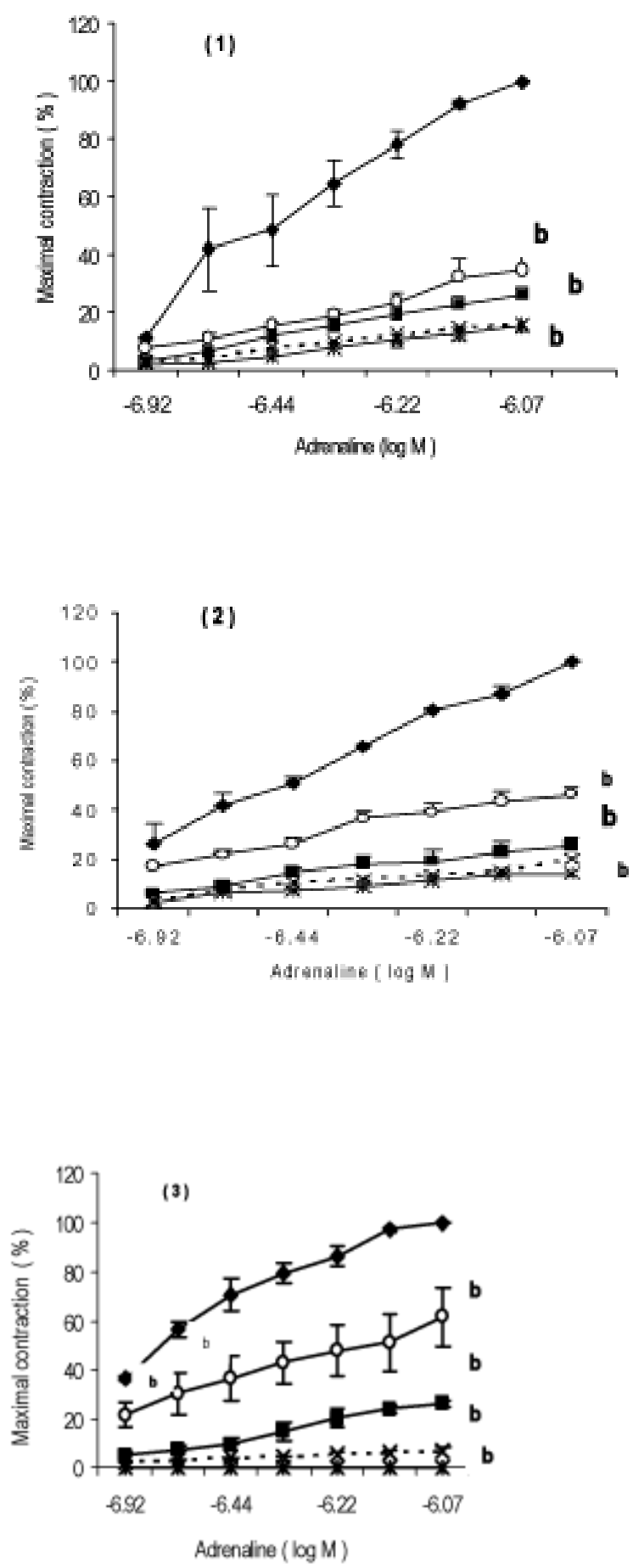

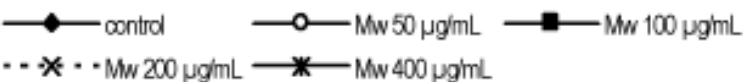


Table 1

Maximal contractile responses of various agonists in the absence and presence of $M$. whitei extract and its fractions (50 $400 \mu \mathrm{g} / \mathrm{ml}$ ) isolated in rat vas deferens

\begin{tabular}{|c|c|c|c|c|c|c|}
\hline \multirow[t]{2}{*}{ Agonist } & \multirow[t]{2}{*}{ M. whitei extract } & \multirow{2}{*}{$\begin{array}{c}\text { In the absence } \\
\text { of M. whitei } \\
\text { (Control) }\end{array}$} & \multicolumn{4}{|c|}{ In the presence of $M$. whitei $(\mu \mathrm{g} / \mathrm{ml})$} \\
\hline & & & 50 & 100 & 200 & 400 \\
\hline $\mathrm{KCl}$ & $\mathrm{CH}_{2} \mathrm{Cl}_{2}: \mathrm{MeOH}$ & $100.00 \pm 0.00$ & $52.24 \pm 4.83^{* *}$ & $45.75 \pm 6.95^{*}$ & $71.19 \pm 8.08^{*}$ & $47.39 \pm 7.37^{* *}$ \\
\hline $\mathrm{KCl}$ & $\mathrm{MeOH}$ & $100.00 \pm 0.00$ & $72.50 \pm 7.27$ & $66.34 \pm 8.82$ & $70.08 \pm 8.19$ & $57.47 \pm 10.56$ * \\
\hline $\mathrm{KCl}$ & Hexane & $100.00 \pm 0.00$ & $72.60 \pm 9.02^{*}$ & $57.14 \pm 2.34^{* *}$ & $46.65 \pm 4.92^{* *}$ & $20.45 \pm 2.78$ ** \\
\hline Adr & $\mathrm{CH}_{2} \mathrm{Cl}_{2}: \mathrm{MeOH}$ & $100.00 \pm 0.00$ & $34.67 \pm 7.52^{* *}$ & $25.97 \pm 2.50$ ** & $15.51 \pm 1.51^{\star *}$ & $15.16 \pm 2.05^{* *}$ \\
\hline Adr & $\mathrm{MeOH}$ & $100.00 \pm 0.00$ & $46.38 \pm 3.28^{* *}$ & $25.18 \pm 3.83^{* *}$ & $20.19 \pm 2.93^{* *}$ & $14.18 \pm 1.06^{* *}$ \\
\hline Adr & Hexane & $100.00 \pm 0.00$ & $61.50 \pm 11.95^{* *}$ & $26.32 \pm 1.44^{* *}$ & $6.12 \pm 1.08^{* *}$ & $3.59 \pm 0.41^{* *}$ \\
\hline $\mathrm{CaCl}_{2}$ & Hexane & $100.00 \pm 0.00$ & $43.61 \pm 4.53^{* *}$ & $27.66 \pm 3.72^{* *}$ & $9.11 \pm 2.78^{* *}$ & $0.00 \pm 0.00$ ** \\
\hline
\end{tabular}

Values are \%maximal response (mean $\pm \mathrm{SEM}) .{ }^{*} \mathrm{P}<0.05$. ${ }^{* *} \mathrm{P}<0.001$ compared to control. Adr - adrenaline.

\section{Table 2}

Percent relaxant activity of $M$. whitei extract and its fractions against $60 \mathrm{mM} \mathrm{KCl}$-induced plateau of contraction in isolated rat vas deferens

\begin{tabular}{lccccc}
\hline Agonist & M. whitei extract & \multicolumn{4}{c}{ M. whitei $(\boldsymbol{\mu g} / \boldsymbol{m l})$} \\
\cline { 3 - 6 } & & $\mathbf{5 0}$ & $\mathbf{1 0 0}$ & $\mathbf{2 0 0}$ & $\mathbf{3 0 0}$ \\
\hline $\mathrm{KCl}$ & $\mathrm{Hexane}$ & $13.67 \pm 5.12$ & $22.52 \pm 4.78$ & $44.22 \pm 4.84$ & $64.37 \pm 4.64$ \\
$\mathrm{KCl}$ & $\mathrm{CH}_{2} \mathrm{Cl}_{2}: \mathrm{MeOH}$ & $8.76 \pm 3.27$ & $18.55 \pm 4.59$ & $40.85 \pm 1.94$ & $52.57 \pm 1.47$ \\
$\mathrm{KCl}$ & $\mathrm{MeOH}$ & $8.15 \pm 1.90$ & $15.89 \pm 0.90$ & $34.52 \pm 2.99$ & $46.23 \pm 5.02$ \\
\hline
\end{tabular}

Values are \%relaxant activity $\left(\right.$ mean \pm SEM). ${ }^{*} P<0.05$ compared with the hexane fraction of $M$. whitei.

Figure 3. Effects of various concentrations of the hexane fraction of Mondia whitei (Mw) on cumulative concentration-response curves to $\mathrm{CaCl}_{2}$. Each point represents mean of four experiments and the bars indicate SEM.

${ }^{a} \mathrm{P}<0.05$ and ${ }^{\mathrm{b}} \mathrm{P}<0.001$ significantly different from the corresponding control.
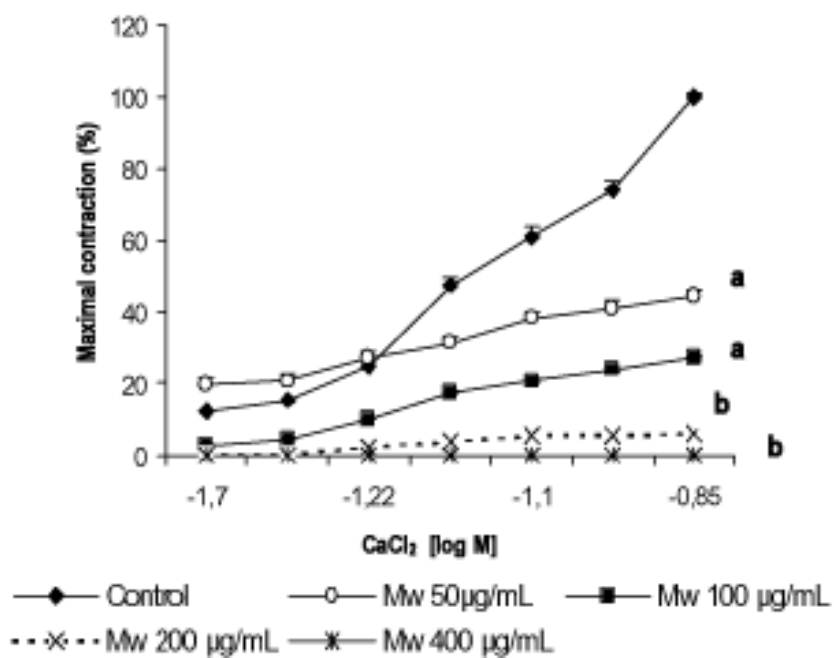

diacylglycerol (DAG). $\mathrm{IP}_{3}$ causes the liberation of the intracellular calcium ion stockage, whereas DAG depolarizes the cell membrane inducing the calcium ions reflux. ${ }^{[11]}$ The stimulation of $\mathrm{a}_{2}$ adrenoceptors activates the adenylcyclase responsible of the increase of cAMP that induces the influx of calcium ions which cause the contraction. ${ }^{[12-15]}$ The rightward shift curves produced by all $M$. whitei extracts against $\mathrm{KCl}$ and adrenaline-induced contraction of the isolated vas deferens denotes noncompetitive antagonism and indicates reduced entry of $\mathrm{Ca}^{2+}$ through membrane $\mathrm{Ca}^{2+}$ channels. ${ }^{[16]}$ This inhibitory effect was prominent at high concentration of hexane fraction $(400 \mu \mathrm{g} / \mathrm{ml})$ of the plant, as compared with that obtained with the $\mathrm{CH}_{2} \mathrm{Cl}_{2}$ : MeOH extract and its methanol fraction. This could be a contributing factor in reducing the continuous transport of sperms at rest and during ejaculation by the vas deferens. Alterations in contractility of rat-isolated vas deferens by many drugs have been reported. ${ }^{[17,18]}$ Our findings also revealed a concentration-dependent relaxing effect of different extracts on the plateau of contraction induced by a supramaximal dose of $\mathrm{KCl}$, and the hexane fraction was found to be more potent than the other two extracts in relaxing the preparation. This ability of $M$. whitei to relax KCl-induced sustained contractions suggests the involvement of voltage-operated calcium channels. 
From these observations, the hexane fraction of $M$. whitei appeared to be the most active. Steroids and aromatic compounds revealed in this extract may be responsible for its high activity ${ }^{[19,20]}$ compared with the other samples in which these substances are either in less quantity $\left(\mathrm{CH}_{2} \mathrm{Cl}_{2}: \mathrm{MeOH}\right.$ extract) or absent (methanol fraction). In order to study the action of $M$. whitei on the movement of external $\mathrm{Ca}^{2+}$, the effect of hexane fraction was examined on the $\mathrm{CaCl}_{2}$-induced contractions in potassium-depolarized preparation. Since this extract was able to abolish the contractions induced by $\mathrm{CaCl}_{2}$ in $\mathrm{K}^{+}$-depolarized preparation in a concentration-dependent manner, it is likely that the hexane fraction of $M$. whitei inhibits the calcium influx through voltage-operated channels.

In conclusion, the results of the present investigation suggest that the hexane fraction of $M$. whitei extracts contains bioactive molecules that block both the receptor-operated and voltage-operated calcium channels, thus preventing the entry of calcium during depolarization of vas deferens by $\mathrm{KCl}$ and adrenaline. However, in vivo studies using the hexane fraction of $M$. whitei are needed to justify and confirm the above assertion.

\section{Acknowledgments}

The authors acknowledge the Third World Academy of Science for the research grant No. 96/002RG/BIO/AF/AC allocated to one of the authors, Professor Albert Kamanyi.

\section{References}

1. Adjanohoun JC, Aboubaker N, Dramane K, Ebot ME, Ekpere JA, EnowOrock EG, et al. Traditional Medicine and Pharmacopoeia. Contribution to ethnobotanical and floristic studies in Cameroon. Lagos: OUA/STRC; 1996.

2. Noumi E, Amvam Zollo PH, Lontsi D. Aphrodisiac plants used in Cameroon. Fitoterapia 1998;69:125-34.

3. Watcho P, Kamtchouing P, Sokeng S, Moundipa PF, Tantchou J, Essame $\mathrm{JL}$, et al. Androgenic effects of the aqueous extract of the roots of Mondia whitei in rats. Asian J Androl 2004;6:269-72.

4. Watcho P, Kamtchouing P, Sokeng S, Moundipa PF, Tantchou J, Essame $\mathrm{JL}$, et al. Reversible antispermatogenic and antifertility activities of Mondia whitei Linn in male albino rat. Phytother Res 2001;15:26-9.

5. Gopala Reddy A, Ravi Prakash V. A study on the characteristics of $\mathrm{Ca}^{2+}$ channels in vas deferens isolated from cyclophosphamide treated rats.
Indian J Pharmacol 1999;31:116-9.

6. Kato K, Tsutsui I, Furuya K, Ozaki T, Yamagishi S. Regional differences in the contractile and intracellular $\mathrm{Ca}^{2+}$ responses of the guinea-pig vas deferens to neurotransmitters and excess $\mathrm{K}^{+}$. Exp Physiol 1995;80:721-33.

7. Schauf $C$, Moffett D, Moffett $S$. Human Physiology. Foundations and Frontiers. St Louis. Missouri: The C.U. Mosby Company; 1990.

8. Mehta AA, Dave KC, Goyal RK. Studies on post-receptor mechanisms in smooth muscle preparations. Indian J Pharmacol 1993;25:228-33.

9. Kuriyama H, Kitamura K, Itoh T, Inoue R. Physiological features of visceral smooth muscle cells, with special reference to receptors and ion channels. Physiol Rev 1998;78:811-20.

10. Chinoy NJ, Chinoy MR. Differential contractile response of normal vas deferens of rodents in correlation to their calcium and electrolytes levels. $J$ Biosci 1983;5:173-80.

11. Exton JH. Regulation of phosphoinositide phospholipases by hormones, neurotransmitters, and other agonists to $\mathrm{G}$ proteins. Annu Rev Pharmacol Toxicol 1996;36:481-509.

12. Bulmann R, Kugelgen I, Stark K. Effect of nifedipine and ryanodine on adrenergic neurigenic contraction of rat vas deferens: evidence for pulseto-pulse change in calcium change in calcium sources. $\mathrm{Br} \mathrm{J}$ Pharmacol 1993;4:1062-70.

13. Loirand C, Cario, Loumaniantz, Chardin P, Pacaud P. Independent inhibition of intestinal smooth muscle. J Cell Physiol 1997;273:816-21.

14. Kato K, Furyya K, Tsutsui Osaki I, Yamagishi S. Cyclic AMP-mediated inhibition of Noradrenaline-induced contractions and calcium influx in guinea pig vas deferens. Exp Physiol 2000;4:387-98.

15. Campos M, Morais PL, Pupo AS. Effect of cyproterone acetate on alpha1adrenoceptor subtypes in rat vas deferens. Braz $\mathrm{J}$ Med Biol Res 2003;36:1571-81.

16. Burgos RA, Aguila MJ, Santiesteban ET, Sanchez NS, Hancke JL. Andrographis paniculata (Nees) induces relaxation of uterus by blocking voltage-operated $\mathrm{Ca}^{2+}$ channels and inhibits $\mathrm{Ca}^{2+}$ influx. Phytother Res 2001;15:263-4.

17. Yaris E, Kesim M, Kadioglu M, Kalyoncu NI, Ulku C, Ozyavuz R. The effects of paroxetine on rat isolated vas deferens. Pharmacol Res 2003;48:335-45.

18. Kalyoncu NI, Ozyavuz R, Karaoglu S. Sertraline inhibits the contractile responses to noradrenaline, $\mathrm{KCl}$ and electrical field stimulation of rat isolated vas deferens. J Auton Pharmacol 1999;19:365-9.

19. Dohle GR, Smit M, Weber RF. Androgens and male fertility. World J Urol 2003;21:341-5.

20. Campos MG, Oropeza MV, Lemus AE, Garcia GA, Reynoso ME, Campos $P$, et al. The androgenic effect of norethisterone and 5 alpha-norethisterone on the contractile response of the rat vas deferens to methoxamine and serotonin. Life Sci 1999;64:227-33.

\author{
Department of Pharmacology \\ Mahatma Gandhi Institute of Medical Sciences, \\ Sewagram, Wardha, \\ Maharashtra - 442102.
}

